Милка В. Николић*

Универзитет у Крагујевцу

Филолошко-уметнички факултет

Катедра за српски језик

https://doi.org/10.18485/ai_zsjoski.2019.2.ch12

821.163.41.09.32 Петровић У.

$811.163 .41 ' 373$

\title{
ЛЕКСИКА САВРЕМЕНЕ СРПСКЕ ПРОЗЕ ЗА ДЕЦУ У 21. ВЕКУ НА ПРИМЕРУ СТВАРАЛАШТВА УРОША ПЕТРОВИЋА**
}

У овом раду се са лингвостилистичког аспекта разматра избор лексике у најновијој српској прози за децу на примеру стваралаштва Уроша Петровића. Корпус истраживања чини једанаест приповедних дела овог аутора. Анализа показује следеће одлике Петровићеве прозе: (a) мање су заступљена одступања од творбених модела, семантичка онеобичавања и уопште јединице са експресивном вредношћу; (б) заступљенија је лексика блиска детету које одраста у доба савремене технологије; (в) укључују се неуметнички жанрови у приповедну прозу. Петровићево опредељење у погледу жанра (епска фантастика, роман у загонеткама) утицало је на избор лексике.

Клучне речи: писац Урош Петровић, српска проза за децу, жанр, стилистички поступак, општи лексички фонд, стилски маркирана лексика.

\footnotetext{
* milkanik75@gmail.com
}

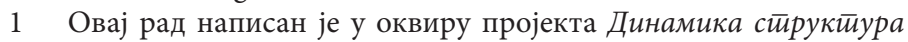
савременої сриискої језика (2011-2019), број 178014, који финансира Министарство науке и просвете Републике Србије. 


\section{1. Увод}

У раду се са лингвостилистичког аспекта сагледава избор лексике у најновијој српској прози за децу на примеру стваралаштва Уроша Петровића (1967). ${ }^{1}$ Стваралаштво овог писаца има висок образовни потенцијал јер код младих читалаца може допринети: (1) развијању маште у свету фантастике, псеудоисторије и словенске митологије; (2) јачању еколошке свести и подстицању поштовања према природи; (2) интересовању за науку и научни начин размишљања; (3) изграђивању истраживачког духа, стваралачког мишљења и примењивог знања. Петровићева литерарна дела привлачна су публици, између осталог, и због начина на који се у његовим делима остварују жанровске конвенције. ${ }^{2}$

Циљ овог рада јесте (1) да се испитају лексика и стилистички поступци којима је захваћен лексички план Петровићеве прозе, као и (2) да се сагледају принципи стилогености његовог избора и употребе лексике. Корпус истраживања чини једанаест приповедних дела, различитих по жанровским одликама.

Лингвостилистичку анализу спроводимо пратећи Петровићев стваралачки приступ од романа Авен и јазойас у Земљи Ваука (2003) до романа Неко се уселио у ону сииару вилу (2018). Очекивано је да се у временском распону од петнаест година мењао пишчев однос

1 Урош Петровић је коаутор програма НТЦ Сисием учења и

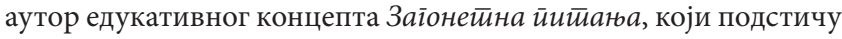
развој функционалног знања и креативног мишљења. Награђен је за допринос култури (2009), за допринос савременом изразу у литератури за децу (2011) и изузетан допринос из области културе и образовања (2014).

2 Истражујући поетичке доминанте најновије српске прозе за децу, Анкица Вучковић (2016) сврстава Петровићево романескно стваралаштво у еклекиичики роман за децу. 
према језичко-стилским вредностима лексике, као што се мењао и жанровски аспект његовог стваралаштва. ${ }^{3}$

\section{2. Теоријски приступ}

Проза Уроша Петровића привукла је пажњу проучавалаца књижевности за децу: (1) истраживане су поетичке особености његовог стваралаштва (в. Главнић 2012; Главнић 2013; Главнић 2014; Паулица 2014a; Паулица 20146; Пешикан Љуштановић 2012a; Пешикан Љуштановић 2012б; Пешикан Љуштановић 2014); (2) разматране су образовне вредности (в. Кљајић 2015); (3) на крају, испитиване су и поједине лингвистичке карактеристике (в. Зорић 2018).

Познаваоци Петровићевог стваралаштва указују да његова приповедна дела треба читати у жанровском кључу. Први његов роман Авен и јазойас у Земљи Ваука (2003) остао је испрва незапажен вероватно зато што публика тада није била спремна за жанр епске фантастике. Услови су се променили наредних година, када су се појавили филмови и компјутерске игре тог жанра.

У стваралаштву овог писца остварују се различити видови фантастике као сложеног жанровског система:

„Истовремено, Петровић се поиграва конвенцијама забавних жанрова, епске фантастике, SF-приче, хорора, кримића али и искорачује из њих често у домен сатире, хумора и анегдотско поентирање властите нарације. У обликовању ликова и сижеа својих приповедака и романа, Петровић води сложен цитатни дијалог са доменом масовне културе и мас-медија: филма, стрипа, музике, али захвата и у домен фолклорне фантастике и усменог демонолошког предања,

3 О принципима лингвостилистичког приступа лексици, в. Ковачевић 2014. 
што придаје његовим приповеткама и романима динамичност и особеност, која не почива на апсолутној оригиналности, већ пре на духовитој и оригиналној комбинаторици познатих прича" (Пешикан Љуштановић 20126: 113).

У нашем корпусу могу се пратити две жанровске линије Петровићеве прозе од првог до најновијег романа (2003-2018): ${ }^{4}$

(a) Романи епске фантастике и хорора: (1) Авен и јазойас у Земљи Ваука; (2) Пейи леййир; (3) Деия Бестираіије; (4) Караван чуgеса;

(б) Романи у загонеткама: (1) Мистиерије Гинкове улице; (2) Мрачне йајне Гинкове улице; (3) Марйина велика заїонейна аванйура; (4) Тајне вешииине Марйе

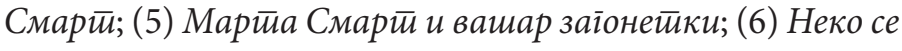
уселио у ону стиару вилу.

Издваја се Прича о Јані̄y, како на жанровском тако и на садржајном плану. Док су остала дела нашег корпуса написана у трећем лицу, у овом делу се приповеда у првом лицу. У нарацију су укључени мањи жанрови (оглас, административни документ о кућном љубимцу), као и одломци обимнијих жанрова (стрип, часопис за децу, енциклопедија паса). Ово је прича о пријатељству између дечака и пса. Мотив „дечак и пас” типичан је за дечју књижевност, међутим, поглед на свет и приказ стварности у Причи о Јаніуy - ближи су одраслом читаоцу.

Жанровске одлике Петровићеве прозе одражавају се на избор лексике и стилистичке поступке којима се делује на лексичке јединице. Резултате стилистичке анализе изложићемо према жанровском кључу, пратећи романе на развојном плану.

4 Дела су наведена према хронолошком редоследу првих издања. 


\section{3. Резултати стилистичке анализе}

\section{1. Романи епске фантастике и хорора}

У романима епске фантастике и хорора радња обухвата шири простор и већи број јунака. Тиме се отвара могућност за стилогену примену поступка именовања, којем писци дечје књижевности посвећују посебну пажњу (в. Максимовић 2010а; Максимовић 2010б).

\subsection{1. Авен и јазойас у Земљи Ваука}

Како показује лингвостилистичка анализа, први српски дечји роман епске фантастике Авен $u$ јазойас $y$ Земљи Ваука има најособенији лексикон у нашем корпусу. Стилистичку доминанту чине ономастика и $\bar{u} е р-$ минолоїија, с тим што ова два система интерферирају. У роману је приказано 17 екосистема на простору Гондване, праконтинента из доба палеозика. Сваком екосистему посвећено је по једно поглавље романа, које почиње својеврсним каталогом биљних и животињских врста карактеристичних за тај екосистем, при чему се за сваку врсту даје (1) „народни” назив и (2) латински назив. Врсте су описане у посебним текстовним сегментима који подсећају на енциклоиееgијске оgреgнице. Веома је велики број номенклатиурних назива биљних и живо-

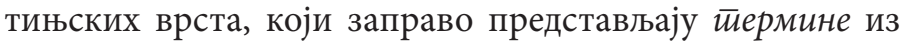
области ботанике и зоологије.

Након описа живог света у екосистему, приповедач прелази на приповедање о авантурама „прадечака” Авена. Употребљена су бројна (1) необична имена ликова, затим, (2) имена животиња, (3) имена необичних бића, а посебна пажња посвећена је називима (4) ужег и ширег простора, као и (5) објеката (мост, тунел, ветрења- 
ча). ${ }^{5}$ Сусрети главног јунака с необичним бићима и авантуре на широком простору - јесу одлике жанра епске фантастике.

Наводимо карактеристичне примере именовања појединачних ентитета (оними) и номенклатурне називе врста (термини): 6

(1) Називи простора и објеката: Гондвана (праконти-

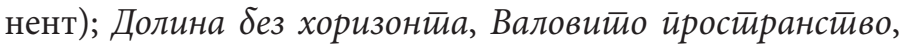
Манірова шума, Луйајуће језеро, Обала уйкуса, Зелено іроитло, Земла Ваука, Царевина баобаба, Прашума Рунаyса (екосистеми); Гоніороg, Тундирон (градови);

(2) Називи објеката и географских појава: Аніејев

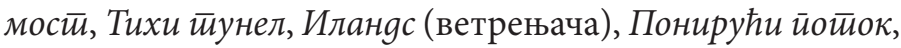
Црно језеро;

(33) Имена ликова: Авен, Улам, Ванй, Ефен, Ивер, Елй, Ича, Андер, Селон, Уі̄o, Крен, Гун, Тлайал, Верйо, Уїзмар, Онвилар, Вијеg, Аниол, Алаї, Мијер, Емӣйо, Лен (мушка имена); Улиса (женско име);

(4) Називи народа: Вилуси, Калемари, Арайи, Суровари, Тундири, Томејии;

(5) Назив за врсту необичних бића: Пенвири;

(6) Имена необичних бића: Сū̄ (име), Кло (надимак);

(7) Имена животиња: Гopg (јазопас), Оул (дивљи кит), Нал (дивљи кит);

(8) Номенклатурни називи биљних врста: корњачурка (Podocnemis loctarius), бругујера (Bruguiera parviflora), метасеквоја (Sequoia glyptostroboides), дивља лубеница (Deya deya), велика боквица (Plantago maior), дуголиста

5 О категоријама у ономастичкој терминологији, в. Шћепановић 2002; Шћепановић 2003.

6 Стилски маркирана лексика у овом раду веома је бројна, што захтева посебан простор за анализу. Овде наводимо само део примера. Овом приликом нећемо се бавити питањем које су биљне и животињске врсте реалне а које измишљене. Познато је да све ове врсте нису постојале у доба палеозоика (нпр. птице и сисари). 
нана (Mentha longifolia), подземна орхидеја (Rhizantela aspergillus);

(9) Номенклатурни називи животињских врста: јазопас (Meles canis), тлозмија (Naja vorus), камилеон (Difer chamaeleo), монал (Lophophorus ihuysi), уткус (Macropus tragocamelus), бабируса (Babyrussa babyrussa), фенек (Fennecus zerda), сцинкуо (Scinus scinus), ампират (Ampiria ratufa), бели мрачњак (Stenocara eburnea), ждеравац росомах (Gulo gulo).

Ономастичке јединице представљају „жижна места” или ,јаке позиције” у тексту, „јер се око њих и у вези са њима све догађа” (Јовић 1975: 133) и „могу послужити као почетна тачка у стилистичком декодирању сваког текста" (Катнић-Бакаршић 2001: 271). ${ }^{7}$ Исто тако, у књижевном тексту су стилски маркиране и терминолошке јединице, јер њихово примарно лексичко окружење припада научном дискурсу.

Међу називима биљака и животиња јављају се речи

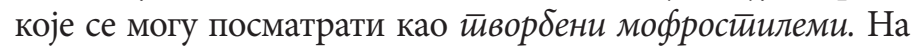
пример, називи врста као што су корғачурка (печурка која подсећа на корњачу), или камилеон (сисар који подсећа на камилу). Издвајају две изузетно дуге и необичне речи:

(а) Пииеехуеgойибероклойиетифинеклойи - назив једне врсте необичних бића, за коју се у роману јавља и назив Пенвири;

(б) Усиееклотиейијуфреgеракехеgасикло - име једног њиховог представника, који има надимак Кло.

7 Употреба онимских јединица у књижевном тексту уопште, као и код појединих писаца, истраживана је у ономастици и стилистици: Бабић 2012; Богдановић 2009; Ђуровић, Спасојевић 2017; Ковачевић 2012; Лилић 2009; Пецо 2007; Саулан 2011; Спасић 2014а; Спасић 20146; Спасојевић 2014; Шимуновић 1976. О доприносу досадашњих лингвостилистичких анализа онимских јединица, в. Шћепановић 2019. 
Постоје и семанйостиилеми, али семантичка померања нису доминантан поступак. Наведимо два примера. У првом, израз gанак у крви употребљен је у дословном значењу, а у другом примеру, израз мритва стиража контрастира с придевом жив, употребљеним у примарном значењу:

Уъези у Земљи Ваука обично умру чим дају gанак у крви (Авен и јазойас, 39).

Улаз у Тунеле је усред Земље Ваука. Ако мрииву сирражу жив йрође, [...] (Авен и јазойас, 133).

Поменућемо још пример који показује како од $а \bar{u} е-$ лайива у говору ликова настаје оним. Израз село изнаg на семантичком (и ортографском) плану трансформише се у назив Село Изнаg и тиме стиче конотације вишег духовног и сазнајног простора:

[Авен:] Ја сам Авен, из села изнаg. [Сип:] Вероватно си видео много више него ја. Ти си из Села Изнаg, кажеш (А вен и јазойас, 21, 22).

Доминантне стилистичке одлике првог романа - ономастичке и терминолошке јединце - у каснијим Петровићевим делима губе доминацију. Његова каснија романескна остварења одликују се мањом заступљеношћу морфостилема и семантостилема. У наредним фазама стваралаштва писац даје предност јединицама општег лексичког фонда, међутим, и даље остају тенденције које су у избору лексике успостављене у првом роману.

\subsection{2. Петии лейӣup}

У роману Петии лейтир, првом српском хорор роману за децу, знатно је ужи опсег простора и мањи број ликова: 
(1) Називи простора: Беоіраg, Међусиианица (гранична зона између живота и смрти), Тара (планина);

(2) Имена ликова: Алекса Рајић Куш, Влаgа Грак, Толстиој (надимак домара у дому за незбринуту децу), Душан, Јовища Вук, Ненаg, Горяан, Алекса Јакшић, наставница Бисенија, баба Сара;

(3) Од необичних бића јављају се духови умрлих: деда Душан, адвокат Јовища Вук, шумар Алекса Јакшић;

(4) Од номенклатурних назива јавља се Picea alexa alexa (врста четинара коју је открио јунак Алекса Рајић).

Именовање у Пейом тейтиру нема вредност стилистичке доминанте. Како на жанровском, тако и на лексичком плану, ово дело доноси заокрет у односу на први роман: писац се одлучио за стилски неутралну лексику, остављајући по страни онеобичавање лексичких јединица.

\subsection{3. Деиа Бестираіије}

Роман Деца Бесйраїије жанровски је сложенији од претходна два остварења: представља комбинацију епске фантастике, авантуристичке бајке, псеудоисторије и словенске митологије. Сличан је првом роману у погледу ширине простора, али има мање имена и номенклайурних назива:

(1) Називи простора: Азија, Сйамбол, Белмониее, Елбрус (само се помињу); Бесиирайија, Балкан, Србија,

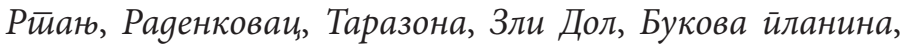
Армавир (планина), Пећина бубюа, Превој оgрон, Врайа йланине, Сйаза йуйника, Бреї немих урлика, Буково село;

(2) Назив објекта: Раскриће (манастир);

(3) Имена ликова: Таса, Рафајло, Клейало, Дауg, Јеврем, Суарай, Кабар, Чауш, Коско, Бжеgух, Суавар, Облак, Цикаваи, Чарайан, Jауg; Ибрахим Баја, Јаро Браяан, Сӣојан Дероюа; Срна (женско име);

(4) Називи народа и становника: Србин, Турчин, Грузин, Ираи; 
(5) Називи становника: Неури, Бестираіичци, Злоgолиц;

(6) Имена животиња: Pec Megaj (пас);

(7) Постоје необичне врсте бића, али те врсте немају посебне називе; исто тако, необична бића немају властита имена;

(8) Номенклатурни називи биљних и животињских врста постоје, али немају посебну стилистичку функ-

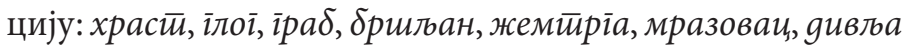
иаротичја, тейтииролики тишај, gивља ружа; мисирски gивљи маіараи, арайски йунокрваи (коњ).

Писац у романескни свет Бесйраіије уводи стару српску митологију и уопште лексику која има културолошку вредност: (а) суіреб, урок, беса, нечисиее силе, Роми Даба; (б) јунаци-дечаци из Бестрагије носе имена демонских бића балканског фолклора - Цикаваи, Чарайан и Jayg.

Јављају се йворбени морбосииллеми различитих

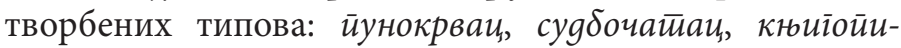
саи, gубодолина, іосиотиримница, ілоіоорран, звонаиија, оиаклија итд. Посебно се издвајају „придеви античког типа": саблолико тишће, лейтиролики тишај, сивооки воgич, риђоgлаки йас, ирвенодлаки йас, јеgнооки Хусар, gуіокоса ілава, gуіоллака мачка итд.

Карактеристична је употреба преименовања једном речју или синтагмом. На пример, за главног јунака употребљавају се изрази: (1) Облак, (2) Безимени, (3) безимени gечак, (4) дечак са Букове йланине, (5) gечак с вијачом, (6) йлавокоси gечак. Јунак Таса именује се на још три начина: (1) Таса С Лойайом, (2) Таса с лойайом, (3) Таса. С лойайом (тачком је обележена парцелација).

Посебну групу примера чине семанйостиллеми, тј. изрази код којих се јављају значењска померања. Наредна два примера показују да овај стилистички поступак омогућава да се смисао исказа афористички или иронично нијансира: 
То је уобичајени начин да се човек сроди са овом земљом!

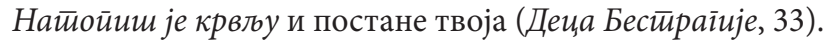
[Рафајло:] Сад ниси једини чији је іроб ирразан. Направио сам себи гроб. [Таса:] Добро, ја сам мој іроб учинио йразним пре него што ће ме сахранити, а ти после! Ти си једини прави ӣразноіроби овде (Деиза Бестираїије, 41).

Фраземи нису чести. Јавља се фразеолошка синтагма у дословном значењу, што доприноси ироничном нијансирању исказа:

Док је уређивао гроб неког претка, тамошњег млинара уgари іром из веgра неба (Деиа Бестираїије, 58).

Роман Деца Бесйраіије тешко је схватљив читаоцима који мало познају жанровске конвенције, као и његов традицијски и митолошки подтекст. Ово Петровићево дело вероватно је најмање отворено према широкој публици и ближе је књижевности за одрасле него дечјој књижевности.

\subsection{4. Караван чуgеса}

У роману Караван чуgеса још је ужи опсег простора и мањи број ликова него у Пейом лейтичру. Ова два Петровићева остварења слична су на жанровском плану - оба романа имају елементе хорора. На лингвостилистичком плану издвајају се малобројни примери необичног именовања:

(1) Назив простора: Граg за Набавку и Разоноgу;

(2) Имена ликова: Agaм, Бурлак (мушки ликови); Ева,

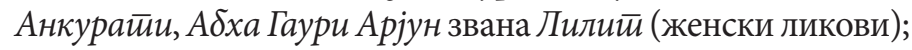

(3) Назив за врсту необичних бића: ирна летеећа мантиа (биће „из другог света”, које „може да ослушкује мисли");

(4) Имена животиња: Хаув (пас), Бисерка (коза); 
(5) Име играчке: Уच̄ō̄o (плишана играчка коала).

Роман Караван чуgеса жанровски је сложен - представља комбинацију научне фантастике, епске фантастике, хорора и параболе о одрастању као авантури. Насупрот жанровској еклектичности, поједностављује се стилистички аспект лексичких јединица: писац не инсистира на стилски маркираној лексици, него предност даје јединицама општег лексичког фонда.

\section{2. Романи у загонеткама}

На жанровском плану, ова прозна остварења приближавају се научно-популарној литератури јер омогућавају двоструко читалачко уживање - у занимљивој причи и у научном сазнавању. У складу с функционалностилистичким одликама научно-популарног подстила, научни

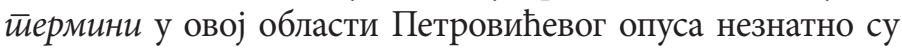
заступљени. Дакле, доминира лексика ойшӣеī фонgа детета које одраста у савременом свету

С друге стране, оними имају стилистичку функцију: имена ликова указују на њихове особине, као што су сналажљивост и оштроумност, односно, тајновитост и необичност, а називи простора указују на загонетност. Наводимо карактеристичне примере:

(1) Називи простора: Гинкова улица (у романима о девојчици Марти Смарт), Улица љьљашки (у роману Неко се уселио у ону стиару вилу);

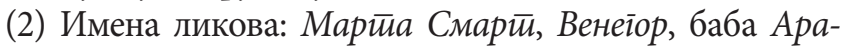
укарија, професор Шизлай (заједнички су за романе о девојчици Марти Смарт); Лукијан, Бакарије Неухваитьиви, Полушой Миіул, Жак Дино, Тойалко, Ними, Вили Величанстивени, јунакиње Луција, Делфина, Болорма и Киси Сйарк (јављају се у појединим романима о девојчици Марти Смарт); Лира („себе [је] назвала Госӣом Луйколиком”), Лун („себе [је назвао] Докйором Изумолоїом”), Веа, Елвира Нула, 
Лил Фјуријус (у роману Неко се уселио у ону ситару вилу);

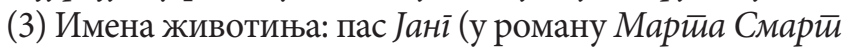
и вамар заїонеикки); стара корњача са Галапагоса која се зове Духоgа (у роману Неко се уселио у ону стиару вилу).

На стилистичком плану, у ових шест романа запажају се следеће одлике: (1) доминира лексика ойшйеі лексичкоі фоонgа; (2) писац не инсистира на сииилски маркираној лексици; (3) смањује се разноврсност стилематичких поступака којима су захваћене лексичке јединице.

\section{3. Прича о Јангу}

Ово дело показује наглашену жанровску разуђеност, чиме се у одређеној мери дезинтегрише приповедна композиција. Писац инкорпорира у текст одређене „ready made" материјале, као што су енциклопедијска одредница, рубрика „Да ли сте знали”, новински оглас, ветеринарски сертификат, фотографија, цртеж, скица, географска карта, плакат.

За разлику од ранијих Петровићевих дела, окренутих традицији и прошлости, од читаоца се сада захтева да влада одређеним културолошком знањем о савременим друштвено-политичким приликама. Наводимо два примера која се односе на међународну изолацију Србије 90-их година прошлог века:

[...] тадашња Србија није била баш симбол живахне међународне ирріовинске размене и сараgюе (Прича о Јані̄y, 16).

[...] ни наше границе нису биле као ниска живища око Лихиенишйајна (Прича о Јаніуу, 19).

Петровић је раније мање користио усииаљене изразе (међу њима и фраземе) док су у овом делу устаљени 
изрази заступљенији. ${ }^{1}$ Њихова функција је најчешће да унесу хумор:

[...] рекао бих да је био умерено хировит пас, што је, опет пажљиво бираним речима, пријатна чињеница да је био луg ко ӣушка (Прича о Јані̄y, 43).

У следећем одломку запажамо како се израз иматии који килоірам вишка уклапа у причу као поента:

Постоји чувена приповест о томе да се у свакоме од нас боре два вука - племенити бели и злокобни црни. На крају победи онај коїа више храниш. Можда нема никакве веза са древном причом, али некако баш волим што је Јанг био бео, и што је одувек имао који килоірам вишка (Прича о JaHīy, 34).

Лексичку особеност Приче о Јаніу представљају називи ирроизвоgа (хрематоними): Зенитиов бойо-айа-

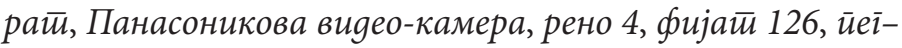
лица (аутомобил), ВХС касейа. Јавља се и друга лексика која подсећа на одређено време: немачке марке (новац),

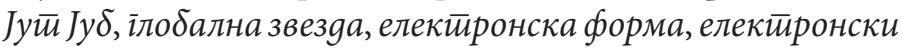

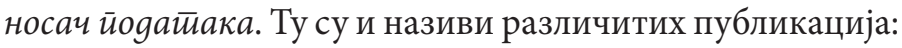

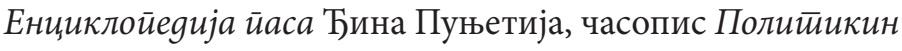
Забавник, часопис Зов, стрип Нииеер. Заступљена је и

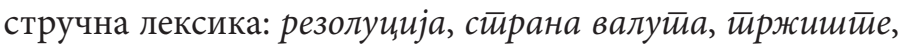
инвестииција, инфлација.

И у овом Петровићевом прозном остварењу јављају се йермини и имена. На пример, расе паса написане су без одступања у односу на стандардне називе: францу-

1 О употреби фразема у различитим функционалним стиловима (посебно у књижевноуметничком стилу), в. Михаљевић, Ковачевић 2006. О употреби фразема у популарној култури, в. Николић, Ђорђевић 2016. 
ски булgоі, gуїоллаки јазавичар, ерgел теријер, беліијски овчар, шар-йеј, велики шнауиер, злайни ретиривер. С друге стране, имена паса подвргнута су посебним стилистичким поступцима: Пройо Наберзи, Тајко Кун, Мејби Романова, Крејзи Настиа, Де Бела Аве Села, Пол Дел Жиі̄оло, Ава Изи Дава, Расӣи Хаус, Алба Ал Замало итд.

Дакле, писац се у Причи о Јаніуy окреће лексици савременог урбаног друштва, уводећи и одређене стилеме на лексичком плану.

\section{4. Закључак}

Посматрано на развојном плану, током година мењао се стваралачки приступ избору лексике у прози Уроша Петровића. Лингвостилистичка анализа показује следеће опште тенденције: (1) мање је морфостилема (необични творбени модели); (2) мање се инсистира на именовању делова стварности за које језик нема име; (3) мање је семантостилема (семантичка померања); (4) мање се инсистира на фраземима, жаргонизмима и другим јединицама са експресивном вредношћу; (5) уводи се лексика блиска детету које одраста у доба савремене технологије; (6) укључују се неуметнички жанрови; (7) уводе се одлике научно-популарног стила (читаоцу се преносе одређене научне чињенице на живописан начин); (8) књиге овог писца представљају мултимедијална дела јер садрже визуелне елементе као што су фотографије, слике, скице.

На жанровском плану, Петровићева романескна остварења су током година све више тежила еклектичком типу романа. На стилистичком плану, лексика показује скоро супротан правац развоја: (1) избор лексичких јединица се све више усмерава ка општем лексичком фонду детета данашњег урбаног друштва; (2) 
писац постепено одустаје од стилски маркиране лексике; (3) смањује се разноврсност стилематичких поступака којима су захваћене лексичке јединице.

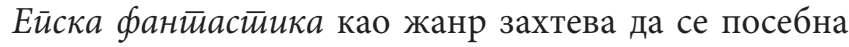
пажња посвети језичко-стилском обликовању и именовању простора. Такође, овај жанр захтева да се стилски изоштрено прикажу авантуре главног јунака, као и све препреке и чудновата бића са којима се он суочава, што опет утиче на избор лексема и стилематичке поступке којима се захвата лексика.

Романи у заіонейкама показују да се писац окренуо популаризацији науке, примењивог знања, стваралачког мишљања и истраживачког духа. Међутим, такав развој није водио ширењу употребе научне терминологије. Одлучујући се за популарну науку, писац је стварао у духу њених функционалностилистичких постулата, а они налажу да текст буде разумљив широком кругу читалаца, што између осталог подразумева доминацију лексике из општег фонда.

\section{Извори}

Авен и јазойас: U. Petrović, Aven i jazopas u zemlji Vauka, Beograd: Laguna, 2015.

Деца Бесӣpaīuje: U. Petrović, Deca Bestrgije, Beograd: Laguna, 2013.

Караван чуgeca: U. Petrović, Karavan čudesa, Beograd: Laguna, 2016.

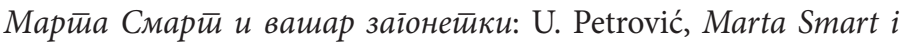
vašar zagonetki, Beograd: Laguna, 2018.

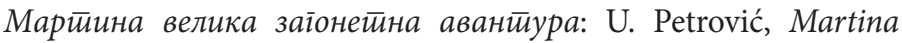
velika zagonetna avantura, Beograd: Laguna, 2014.

мистиерије Гинкове улице: U. Petrović, Misterije Ginkove ulice, Beograd: Laguna, 2008.

Мрачне йајне Гинкове улище: U. Petrović, Mračne tajne Ginkove ulice, Beograd: Laguna, 2018. 
Неко се уселио у ону стиару вилу: U. Petrović, Neko se uselio и опи staru vilu, Beograd: Laguna, 2018.

Петии леӣ̄uир: U. Petrović, Peti leptir, Beograd: Laguna, 2015.

Прича о Јані̄y: U. Petrović, Priča o Jangu, Beograd: Laguna, 2017.

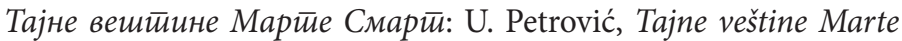
Smart, Beograd: Laguna, 2016.

\section{Литература}

Бабић 2012: М. Бабић, Међузависност начина именовања ликова и вриједносне тачке гледишта у Проклет̄ој авлији Ива Андрића, Срйски језик, XVII/1-2, Београд, 81-94.

Богдановић 2009: Н. Богдановић, Именослови српских писаца, у: А. Савић-Грујић, Н. Богдановић (ур.), Именослови срӣских йисаияа. Писии и језик 2, Ниш: Филозофски факултет, 5-6.

Вучковић 2016: А. Вучковић, Срйски роман за gеиу на йочетику 21. века у свеитлу книжевних наїраgа (2001-2010), Докторска дисертација, Нови Сад: Филозофски факултет.

Главнић 2012: Г. Главнић, О фантастичним романима за децу Уроша Петровића, Детиинссивво, 3, Нови Сад, 66-74.

Главнић 2013: Г. Главнић, Ода слободи Уроша Петровића, Детииғьсииво, 4, Нови Сад, 62-70.

Главнић 2014: Г. Главнић, Загонетање Уроша Петровића или похвала мудрости 21. века, Детиинстиво, 4, Нови Сад, 84-101.

Ђуровић, Спасојевић 2017: С. Ђуровић, М. Спасојевић, Стилска функција антропонимијских јединица у роману Време кокошки Добрила Ненадића, у: М. Ковачевић, Ј. Петко-

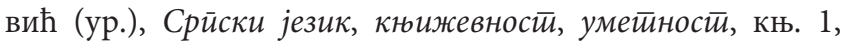
(Срйски) језик у комуникайивној функиији, Краујевац: ФИЛУМ, 179-188.

Зорић 2018: М. Зорић, О неким функцијама аориста у роману Деияа Бестираїије Уроша Петровића, у: В. Јовановић, Б. Илић (ур.), Кюижевности за децу у науии и настиави, Јагодина: Педагошки факултет, 103-111. 
Јовић 1975: D. Jović, Lingvostilističke analize, Beograd: Društvo za srpskohrvatski jezik i književnost.

Катнић-Бакаршић 2001: M. Katnić-Bakaršić, Stilistika, Sarajevo:

Naučna i univerzitetska knjiga.

Кљајић 2015: Н. Кљајић, Авен и јазойас у Земљи Ваука Уроша Петровића у корпусу изборне лектире - пут ка канонизацији, Детииғьсичво, 2, Нови Сад, 119-131.

Ковачевић 2012: М. Ковачевић, Стилистика онимских назива у роману Јойей суgанија Тихомира Левајца, у: М. Ковачевић,

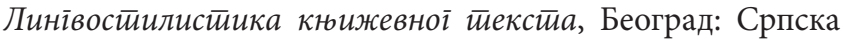
књижевна задруга, 297-309.

Ковачевић 2014: М. Ковачевић, стилематична лексика у роману Agресар изіубльених gуша Анђелка Анушића, у: М. Ковачевић (ур.), Наука и ілобализација, књ. 1/1, Источно Сарајево: Филозофски факултет, 115-129.

Лилић 2009: Д. Лилић, Структура именослова романа Слободана Џунића, у: А. Савић-Грујић, Н. Богдановић (ур.), Именослови срйских йисаия. Писии и језик 2, Ниш: Филозофски факултет, 85-104.

Максимовић 2010a: Ј. Максимовић, Антономазијски принципи именовања у именима ликова у књижевности за децу, у: С. Денић (ур.), Савремени тиренуйак книжевностии за gеиу у настиави и науиз, Врање: Учитељски факултет, 202-214.

Максимовић 2010б: Ј. Максимовић, Тмезички каламбур у антономазијским именима ликова књижевности за децу, у: В. Јовановић, Т. Росић (ур.), Савремена книжевносит за gецу у науци и настиави, Педагошки факултет Јагодина, 149-159.

Михаљевић, Ковачевић 2006: М. Mihaljević, В. Kovačević, Frazeologizmi kroz funkcionalne stilove, Jezik, Zagreb, 53/1, $1-15$.

Николић, Ђорђевић 2016: М. Николић, В. Ђорђевић, Модификације фразеологизама у српској реп музици, у: Ј. Петковић, М. Ковачевић (ур.), Срйски језик, кюижевности, уме-

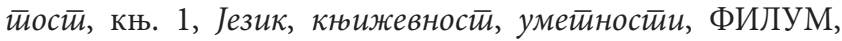
Крагујевац, 423-431.

Паулица 2014a: Н. Паулица, Јунак савременог фантастичног романа за децу и младе (на примеру романа Нила Гејмена 
и Уроша Петровића), у: В. Јовановић, Т. Росић (ур.), Кюи-

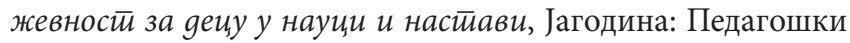
факултет, 329-341.

Паулица 20146: Н. Паулица, Хронотоп савременог фантастичног романа за децу и младе (на примеру романа Нила Гејмена и Уроша Петровића), Детиинстиво, 4, Нови Сад, 75-84.

Пецо 2007: A. Peco, Lično ime u Sijarićevom romanu Bihorci, u: A.

Peco, Jezik književnog teksta. Bibliografija, Izabrana djela, VI, Sarajevo: Bosansko filološko društvo, 327-338.

Пешикан Љуштановић 2012а: Љ. Пешикан Љуштановић,

Сироче међу духовима - Петии лейиир Уроша Петровића и Кюиі̄a о іробљу Нила Гејмена, у: Љ. Пешикан Љуштановић, Госйођи Алисиној gесној нози, Нови Сад: Змајеве дечје игре, 127-135.

Пешикан Љуштановић 2012б: Љ. Пешикан Љуштановић, Фантастични свет у стваралаштву Уроша Петровића - између хорора и хумора, у: Љ. Пешикан Љуштановић, Госӣођи Алисиној gесној нози, Нови Сад: Змајеве дечје игре, 113127.

Пешикан Љуштановић 2014: Љ. Пешикан Љуштановић, Простор у фантастичном роману за децу - нацрт типологије на примерима савремене српске прозе, у: В. Јовановић, Т. Росић (ур.), Кюижевности за деиу унауии и настиави, Јагодина: Педагошки факултет, 11-34.

Саулан 2011: D. Saulan, Leksička analiza mitopetskog imenovanja u Revizoru N. V. Gogolja, Onomastica jugoslavica, XX, Zagreb, 173-188.

Спасић 2014а: Ј. Спасић, Антономазија у поезији Хиланgарија, Уздании, , XI/2, 35-45.

Спасић 20146: Ј. Спасић, Восијанска антономазија - вишезначност антропонима, у: М. Ковачевић (ур.), Срӣски језик,

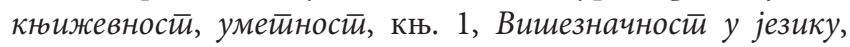
Крагујевац: Филолошко-уметнички факултет, 135-145.

Спасојевић 2014: М. Спасојевић, Комизам антропонима и когномена у делима Бранка Ћопића, у: Б. Тошовић, Лирски, хумористиччки и сатичрички свијет̄ Бранка Ћойића, књ. 
3. Ћойићево моделоваюе реалностии кроз хумор и саиииру, Грац: Институт за славистику Универзитета Карл Франц, Бања Лука: Народна и универзитетска библиотека, 347360.

Шимуновић 1976: P. Šimunović, Ime u funkciji književnoga djela, Onomastica jugoslavica, VI, Zagreb, 241-252.

Шћепановић 2002: М. Шћепановић, Зооним као ономастички термин, Срӣски језик, VII/1-2, Београд, 321-327.

Шћепановић 2003: М. Шћепановић, Српска ономастичка терминологија, Свей речи, 15-16, Београд, 14-16.

Шћепановић 2019: М. Шћепановић, Оними под лупом лингвостилистике, Срйски језик, XXIV/1-2, Београд, 127-134.

Milka Nikolić

\section{LEXIS OF CONTEMPORARY SERBIAN PROSE FOR CHILDREN IN THE $21^{\text {th }}$ CENTURY DEMONSTRATED ON THE EXAMPLE OF UROŠ PETROVIĆ'S WORKS}

This paper discusses the choice of lexis in the present-day Serbian prose for children using the works of Uroš Petrovic from the stylistic aspect. The corpus of study is comprised of eleven narrative works of the writer. The analysis showed that, comparing to the writers with similar creative approach, Petrovićs prose has the following characteristics: (1) it applies less unusual word formation models; (2) it insists less on naming the parts of reality for which there is no name; (3) it applies less meaningful word shifts; (4) it insists less on phrasemes, jargons, and other units with expressive value; (5) it introduces lexis known to a child that is growing up in the age of modern technology; (6) it includes non-artistic genres in narrative prose; (7) it vividly conveys the scientific facts, slightly using the scientific terms; (8) the books of the writer contain visual elements (photography, images, sketches, graphic representation of 
a text). We can conclude that the writer's option of genre affected stylistic methods by which stylistically neutral lexical units transform into stylistically marked. Epic fantasy as a genre requires that the attention is directed towards the linguo-stylistic moulding of space, as well as that a main character's adventure is shown, which influenced the choice of lexis.

Key words: writer Uroš Petrović, Serbian prose for children, genre, stylistic methods, general lexical range, stylistically marked lexis. 